\title{
Congenital heart diseases: A review of echocardiogram records
}

\author{
Md. Saiful Islam, Md. Moniruzzaman ${ }^{2}$
}

\begin{abstract}
Congenital heart defect (CHD) means an anatomic malformation of the heart or great vessels which occurs during intrauterine development, irrespective of the age at presentation. They can disrupt the normal blood flow through the heart. The blood flow can slow down, go in the wrong direction or to the wrong place, or be blocked completely. Broadly congenital heart defects can be acyanotic and cyanotic. We have reviewed retrospectively from echocardiogram record nearly two years of period \& collected total 404 patients with congenital heart defects. Among them 329 (81.43\%) was acyanotic and 75 (18.57\%) was cyanotic congenital defects with variety of diagnosis. Ventricular septal defect was the most common acyanotic heart defect and Tetralogy of Fallot was the most common cyanotic heart defect. There was no significant gender deference.
\end{abstract}

Keywords: Acyanotic, Congenital heart disease, Cyanotic.

Date of received: 11. 11. 2017

Date of acceptance: 05. 01. 2018

\section{Introduction}

Congenital heart defects (CHD) are reported in almost $1 \%$ of live births, and about half of these children need medical or surgical management in infancy ${ }^{1}$. In the first decade, a further $25 \%$ require surgery to maintain or improve their life ${ }^{1}$. Only $10 \%$ survive to adolescence without specific treatment. Of these $10 \%$ many live a normal life for years before their abnormality is detected ${ }^{1}$. This would result in birth of 25,000 to 35,000 infants with CHD each year in the United States alone. Congenital heart defects are more common than others well-known congenital anomalies such as congenital pyloric stenosis, cleft lip, Down syndrome and congenital dislocation of the hip. About 500,000 patients in the USA alone have survived into adulthood with congenital heart disease with about 20,000 additional patients reaching adulthood each year $^{2-4}$. The cause of congenital heart defects is largely unknown and the majority of them may be explained by multifactorial inheritance hypothesis. Extensive research on gene mapping that is currently in progress may explain previously unknown genetic mechanisms for $\mathrm{CHD}^{5}$. This study was done to find out the pattern \& prevalence of congenital heart defects in a rural based tertiary care cardiac center at Department of Cardiology, Khwaja Yunus Ali Medical College \& Hospital, Enayetpur, Sirajgonj.

\section{Etiology}

The cause of all congenital cardiac defects is not exactly known. The majority of the defects can be explained by multifactorial inheritance hypothesis which states that a predisposed fetus, when exposed to a given environmental trigger, to which the fetus is sensitive during the critical period of cardiac morphogenesis may develop the disease ${ }^{5}$. A variety of factors have association with certain heart defects and these may be termed risk factors. Maternal rubella, Coxsackie B virus infection during pregnancy, drugs like thalidomide, some anticonvulsant drugs, Lithium, folic acid antagonists, cocaine, excess alcohol during pregnancy have relationship with congenital heart defects. A higher incidence of cardiac abnormalities with maternal diabetes is well known. Gross chromosomal anomalies such as trisomy 21 (Down syndrome), trisomy D and E syndromes, Turner's syndrome (XO) are associated with a higher incidence of heart defects ${ }^{6}$. Both autosomal and sex-linked single mutant gene syndromes have been reported with CHD. In the presence of family history of congenital heart defect the probability of CHD in the offspring is higher than that seen in general population ${ }^{6}$.

\section{Classification}

Congenital heart defects may be classified into acyanotic and cyanotic depending upon presence of cyanosis. The acyanotic defects may further be subdivided into obstructive lesions and left-to-right shunt lesions. The cyanotic defects, by definition, have right-to-left shunt. Although divided into cyanotic and acyanotic, there are several conditions that start acyanotic and

1. Professor \& Head, Department of Cardiology, Khwaja Yunus Ali Medical College \& Hospital, Sirajgonj, Bangladesh.

2. Assistant Professor, Department of Cardiology, Khwaja Yunus Ali Medical College \& Hospital, Sirajgonj, Bangladesh.

Correspondence: Md. Saiful Islam, Professor \& Head, Department of Cardiology, Khwaja Yunus Ali Medical College \& Hospital, Enayetpur, Sirajgonj, Bangladesh. Phone: +88 01711-116132, e-mail: drsaiful11th@gmail.com 
become cyanotic with time. Table shows the most common lesions presenting in a neonate and those presenting in the infant and older child. Most congenital heart disease should be detected by a good neonatal examination or at a 6 -week checkup $^{7,8}$.

\section{Evaluation of patients}

Not all patients are always symptomatic. Symptoms depend on types and severity of disease. Clinical signs also depend on underlying congenital defects. Some noninvasive testing are usually helps to reach the diagnosis. Cardiac catheterization and selective cineangiography are needed for selected cases.

- Noninvasive evaluation- ECG, Chest x-ray, Echocardiogram

- Invasive- Cardiac catheterization and selective cineangiography

\section{Materials and methods}

This review study was done at Echocardiography lab. at Department of Cardiology, Khwaja Yunus Ali Medical College \& Hospital, Enayetpur, Sirajgonj. All patients who had a congenital anomaly on transthoracic echocardiography were included in the study despite of age and sex. Echocardiography was done with Philips Affinity 70C. The machines have capabilities to perform M-mode, twodimensional, and Doppler examinations. The echocardiographic examinations were performed and interpreted by consultant cardiologists. All measurements were taken from standard echocardiographic views according to the recommendation of the American Society of Echocardiography ${ }^{9}$. Data obtained from the echo register included age, gender, clinical diagnosis, and specific congenital defects \& were analyzed with a computer using SPSS version 21 software.

\section{Results}

We have analyze total 404 patient with congenital heart disease over nearly two years of period presented at our Echocardiography lab, among them $329(81.43 \%)$ patients had acyanotic congenital heart defect and $75(18.57 \%)$ patients had cyanotic congenital heart defect. Among the acyanotic patients, $164(49.85 \%)$ was male and 165 (50.15\%) was female and among the cyanotic patients, $42(56 \%)$ was male and $33(44 \%)$ was female. (Table I)

Table I: Types and gender distribution of Congenital heart defects $(n=404)$

\begin{tabular}{|c|cccc|}
\hline \multirow{3}{*}{$\begin{array}{c}\text { Congenital Heart } \\
\text { Disease }\end{array}$} & \multicolumn{2}{|c}{$\begin{array}{c}\text { Acyanotic } \\
\text { (n=329) }\end{array}$} & \multicolumn{2}{c|}{$\begin{array}{c}\text { Cyanotic } \\
(\mathbf{n}=75)\end{array}$} \\
\cline { 2 - 5 } & Male & Female & Male & Female \\
\cline { 2 - 5 } & $164(49.85 \%)$ & $165(50.15 \%)$ & $42(56 \%)$ & $33(44 \%)$ \\
\hline
\end{tabular}

Among the acyanotic congenial heart defects ventricular septal defect was more common 142 (43.16\%) followed by Atrial septal defect 93(28.2\%) \& Patent Ductus Arteriosus 30(9.1\%). $43(13.07 \%)$ had combined defects. (Table II) (Figure 1, 2, 3)

Table II: Distribution of Acyanotic congenital heart defects $(n=329)$

\begin{tabular}{|ccccc|}
\hline Diagnosis & $\mathbf{0 - 1 0}$ years & $\begin{array}{c}\mathbf{1 1 - 2 0} \\
\text { years }\end{array}$ & $\begin{array}{c}>\mathbf{2 0} \\
\text { years }\end{array}$ & Total, $\mathrm{n}(\%)$ \\
\hline Ventricular Septal Defect & 102 & 21 & 19 & $142(43.16 \%)$ \\
Atrial Septal Defect & 22 & 11 & 60 & $93(28.26 \%)$ \\
Patent Ductus Arteriosus & 21 & 06 & 03 & $30(9.11 \%)$ \\
Mitral Valve Prolapse & 01 & 00 & 07 & $08(2.43 \%)$ \\
Bicuspid Aortic Valve with & 01 & 00 & 01 & $02(0.6 \%)$ \\
AS & 02 & 02 & 01 & $05(1.5 \%))$ \\
Pulmonary Stenosis & 01 & 00 & 05 & $06(1.82 \%)$ \\
Dextrocardia & 01 & 07 & 13 & $43(13.07 \%)$ \\
Combined defects & 23 & & & \\
\hline
\end{tabular}

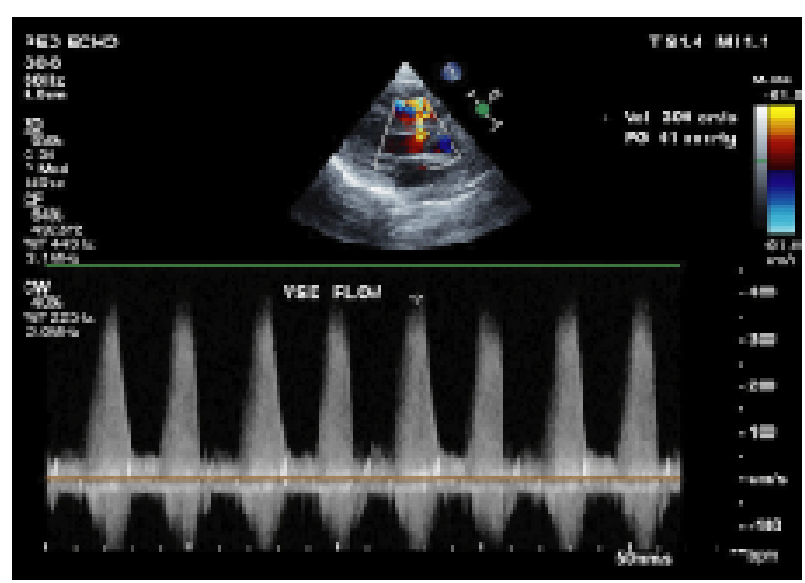

Figure 1: Doppler Echocardiography shows VSD flow.

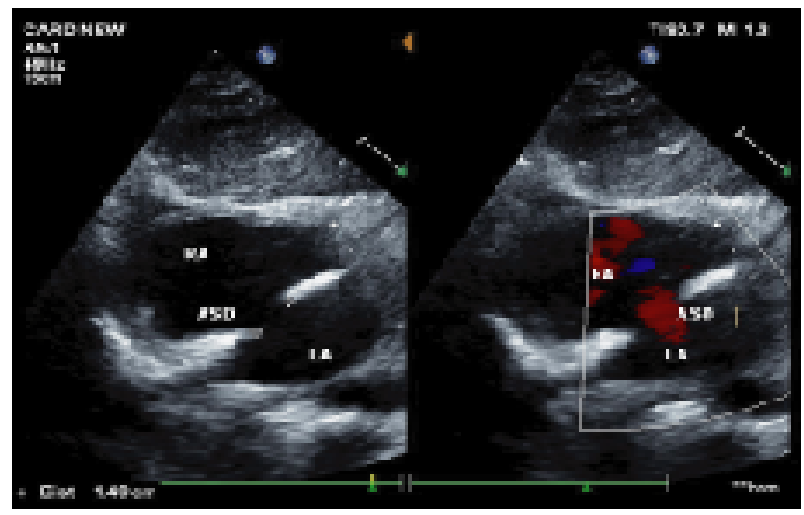

Figure 2: Doppler Echocardiography shows ASD (Secundum) flow. 


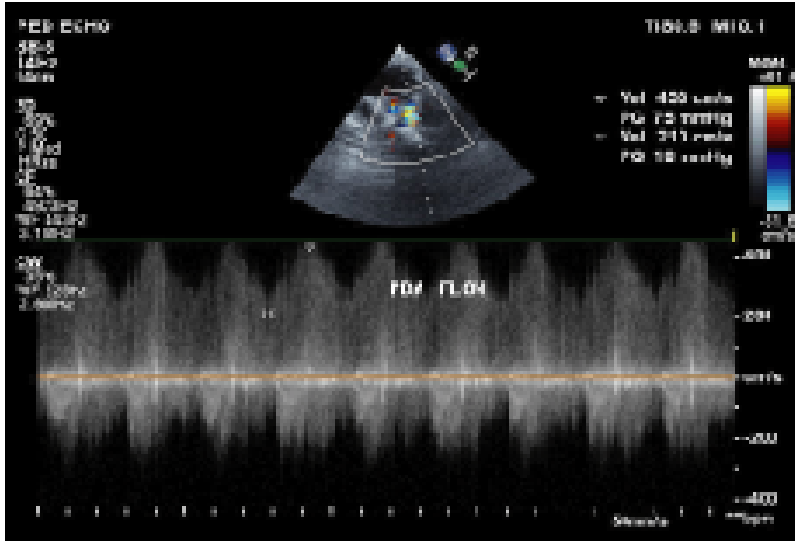

Figure 3: Doppler Echocardiography shows PDA flow.

Among the cyanotic congenial heart defects commonest disease was Tetralogy of Fallot 59(78.7\%). Cyanotic heart disease are mostly presented in earlier age. (Table III) (Figure 4)

Table III: Distribution of Cyanotic congenital heart defects $(\mathrm{n}=75)$

\begin{tabular}{|ccccc|}
\hline Diagnosis & $\mathbf{0 - 1 0}$ years & $\mathbf{1 1 - 2 0}$ years & $\mathbf{> 2 0}$ years & Total, $\mathbf{n}(\%)$ \\
\hline Tetralogy of Fallot & 40 & 16 & 03 & $59(78.7 \%)$ \\
Transposition of great & 02 & 00 & 00 & $02(2.7 \%)$ \\
vessels & & & & \\
Complex Congenital & 04 & 00 & 00 & $04(5.3 \%)$ \\
Tricuspid Atresia & 02 & 00 & 01 & $02(2.7 \%)$ \\
$\begin{array}{c}\text { Pulmonary Valvular atresia } \\
\text { with VSD/PDA }\end{array}$ & 06 & 00 & 00 & $06(8.0 \%)$ \\
Severe Ebstein anomaly & 00 & 00 & 02 & $02(2.7 \%)$ \\
\hline
\end{tabular}

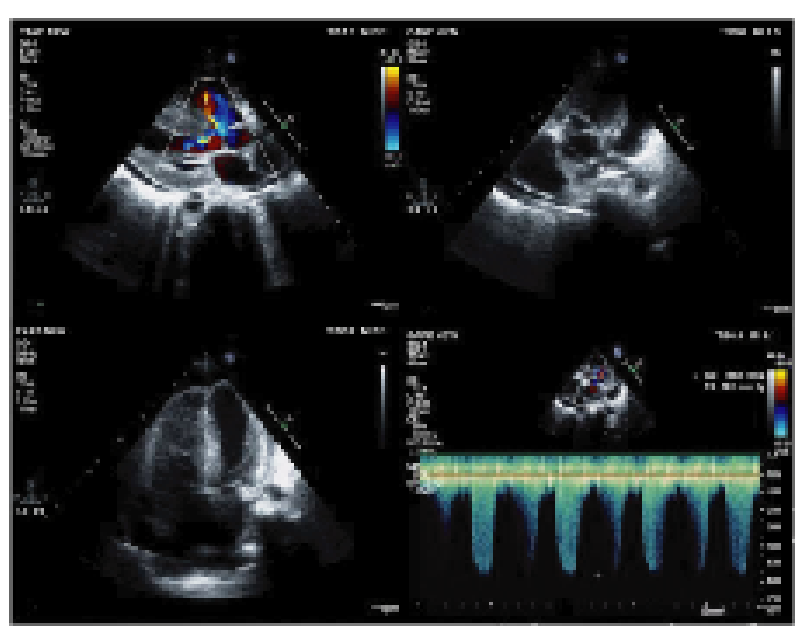

Figure 4: Doppler Echocardiography shows typical findings of TOF- VSD, overriding of aorta, RV outflow tract obstruction \& RV hypertrophy.

There was no significant gender deference but incidence of ASD \& PDA was higher in female and VSD was more in male. In cyanotic heart disease incidence of TOF was slightly higher in male.

\section{Discussion}

Many study done previously based on congenital heart disease. We have reviewed echo reports of congenital heart disease at out Echocardiography lab. to see our current status. This study showed there was no statistically significant difference in the mean ages of males and females affected by the different congenital heart diseases, or in the frequency between both genders. VSD, ASDs, and TOF, in that order, were the most common congenital abnormalities seen in adults in this study. Our findings are similar to the studies done elsewhere ${ }^{10}$. Atrial septal defects were significantly more prevalent in females in this study, and this finding has been documented both in children and adults by previous studies ${ }^{11}$. Persistent ductus arteriosus was also more frequent in females, but the difference was not statistically significant, most of the study in past found that PDA is more frequent in female. It is noteworthy that bicuspid aortic valve was found only in one patient in this study. Combined defects are also not uncommon. TOF was more frequent in males. Varying results have been documented in the past by different researchers on the gender differences in the prevalence of $\mathrm{TOF}^{12,13}$. Frequency of Tricuspid atresia and Complex congenital heart diseases are next to TOF.

\section{Conclusion}

Ventricular septal defect (VSD) is the most common acyanotic congenital defect followed by Atrial Sepal Defect (ASD) \& Patent Ductus Arteriosus (PDA). VSD and PDA mostly present in earlier age \& ASD mostly present in adult age. Among the cyanotic heart diseases Tetralogy of Fallot is commonest \& present in early age group. There is no statistically significant gender difference.

\section{References}

1. Ashley EA, Niebauer J. Cardiology Explained. Ch. 14. London: Remedica;2004. Adult congenital heart disease. Available from: http://www.ncbi.nlm. nih.gov/books/ NBK2212. Access on 14th October.

2. Shiina Y, Toyoda T, Kawasoe Y, Tateno S, Shirai T, Wakisaka Y, et al. Prevalence of adult patients with congenital heart disease in Japan. Int $\mathrm{J}$ Cardiol. 2011;146:13-16.

3. Perloff JK. Medical center experiences. J Am Coll Cardiol. 1991;18:315-318.

4. McNamara DG. The adult with congenital heart disease. Curr Probl Cardiol. 1989;14:57-114.

5. Nora, J. J. Multifactorial inheritance hypothesis for etiology of congenital heart disease: the genetic- environmental interaction. Circulation, 1968;38(3):604-17.

6. Rao, P. S. Prevention of heart disease in infants and children. Current Prob Pediat, 1977;7(7):p.1-48.

7. Swanton's Cardiology: A concise guide to clinical practice Sixth Edition By R. H. Swanton and S. Banerjee (C) 2008 R $\mathrm{H}$ Swanton and S Banerjee. ISBN: 978-1-405-178198,p.17. 
8. Jamil A, Aboulhosn and John s.Child, congenital Heart Diseas in Adults. Hurst's The Heart. Manual of Cardiology 13 th ed.p.513.

9. Quiñones MA, Otto CM, Stoddard M, Waggoner A, Zoghbi WA Doppler Quantification Task Force of the Nomenclature and Standards Committee of the American Society of Echocardiography. Recommendations for quantification of Doppler echocardiography: A report from the Doppler Quantification Task Force of the Nomenclature and Standards Committee of the American Society of Echocardiography. J Am Soc Echocardiogr. 2002;15:167-184.

10. Ardiç I, Kaya MG, Kasapkara A, Sarli B, Dogdu O, Dogan
A, et al. Evaluation of adult congenital heart diseases. Turk Kardiyol Dern Ars. 2010;38:25-31.

11. Ejim EC, Anisiuba BC, Ike SO, Essien IO. Atrial septal defects presenting initially in adulthood: Patterns of clinical presentation in Enugu, South-East Nigeria. J Trop Med. 2011;251:9-13.

12. Samánek M. Boy: girl ratio in children born with different forms of cardiac malformation: A population-based study. Pediatr Cardiol. 1994;15:53-57.

13. Daliento L, Dal Bianco L, Bagato F, Secco E, Sarubbi B, Mazzotti E, et al. Gender differences and role of pregnancy in the history of post-surgical women affected by tetralogy of Fallot. PLoS One. 2012;7:e49729. 